\title{
Systemic Herpes Simplex Infection in a Newborn Treated with Intravenous Idoxuridine
}

\author{
J. W. PARTRIDGE and ROSEMARY R. MILLIS \\ From the Departments of Paediatrics and Pathology, Addenbrooke's Hospital, Cambridge
}

Idoxuridine (5-iodo-2'-deoxyuridine) is a thymidine analogue which interferes with deoxyribonucleic acid (DNA) metabolism and inhibits herpes simplex virus multiplication. Its systemic use is limited by toxicity. Calabresi (1965) has recommended that it be used only for severe infections with DNA-containing viruses, or for malignant disease.

We report a newborn infant with severe herpes simplex infection; idoxuridine was used systemically with some evidence of effectiveness, though cessation of treatment was followed by relapse and death.

\section{Case Report}

The course of the illness is shown in Fig. 1. The patient, a girl, was born at term, and weighed $3.86 \mathrm{~kg}$. The mother was primigravid and had never noted labial or genital herpes, though her husband had recurrent labial 'cold sores', the last episode being 6 months before the baby's birth.

The membranes ruptured spontaneously 81 hours before delivery. No herpetic genital lesions were noted before, during, or after labour. The liquor became offensive and the mother's temperature rose to $38.8^{\circ} \mathrm{C}$. The baby was born spontaneously after a 48-hour labour. She was slow to breathe and required resuscitation by endotracheal intubation and inflation. Respiration was established within 10 minutes. On the first day of life, she was irritable, with a serous eye discharge. Throat and eye swabs were bacteriologically sterile and she remained afebrile. Breast feeding was established.

On the 4th day she became febrile and sucked less well but was still alert and active: 5 crusting vesicles were now noticed on the neck, 2 intact vesicles on the chest, and 4 in the axilla. On the 7 th day she was slightly breathless. The respiration rate was $60 / \mathrm{min}$., the alae nasi were working, and there were a few fine crepitations at the lung bases. The liver was palpable $2 \mathrm{~cm}$. below the costal margin. Chest $x$-ray showed patchy confluent opacities in the right lower zone (Fig. 2a).

On the 10th day she was less well, with profuse, yellowish, mucopurulent nasal and pharyngeal secre-

Received February 8, 1968. tions, and laboured, noisy breathing. The liver was palpable $5 \mathrm{~cm}$., and the spleen $2 \mathrm{~cm}$., below the costal margin. The vesicles were larger and a new group had appeared on the shoulder (Fig. 3). Vesicle fluid and nose and throat swabs were collected for virus culture: herpes simplex virus was subsequently isolated from all of these (see Table III). On the 11th day she was semicomatose, with head retraction. Examination of lumbar CSF showed a pleocytosis suggesting a virus infection (Table I). A throat swab collected on the previous day grew 'coliform bacilli', and colistin, chloramphenicol, and prednisone were given.

On the 13th day the baby was severely ill and had two apnoeic attacks. Chest $x$-ray showed opacities in the right upper zone (Fig. 2b), and an ECG showed abnormal QRS complexes with S-T elevation (Fig. 4a). Following identification of the virus, it was decided to use idoxuridine which was given by an infusion through a scalp vein needle for 5 days, from the 13th to the 17th day (Table II). Although it ran into the tissues for short periods there was no local reaction.

She was slightly better 48 hours after starting idoxuridine. No new vesicles had appeared and those present were resolving. By the 22nd day she was considerably improved, alert, hungry, and taking some bottle feeds. The $x$-ray appearances of the chest (Fig. 2c) and the ECG appearances (Fig. 4b) had improved. The clinical improvement was gradual but definite, though at no time did she return to completely normal health and it was feared that there had already been irreversible brain damage.

On the 23rd day of life 2 new vesicles appeared on the right shoulder. 2 days later vesicles reappeared at the previous site on the left chest. Topical idoxuridine was applied to them, and also to a mild dry scaly rash on the face. A dose of $4 \cdot 7 \mathrm{ml}$. $\gamma$-globulin was given intramuscularly. On the 27th day she rapidly deteriorated with considerable respiratory distress. A second course of idoxuridine was started together with prednisone and colistin. She died the next day, aged 28 days, having received $250 \mathrm{mg}$. idoxuridine in the previous 12 hours.

When herpes simplex virus was isolated from the baby, the mother was examined for herpetic ulcers or vesicles. None were seen on her face, lips, mouth, vulva, or vagina (the cervix was not examined). The vaginal swab yielded herpes simplex virus. The mother was examined again 43 days post partum but no lesions were 


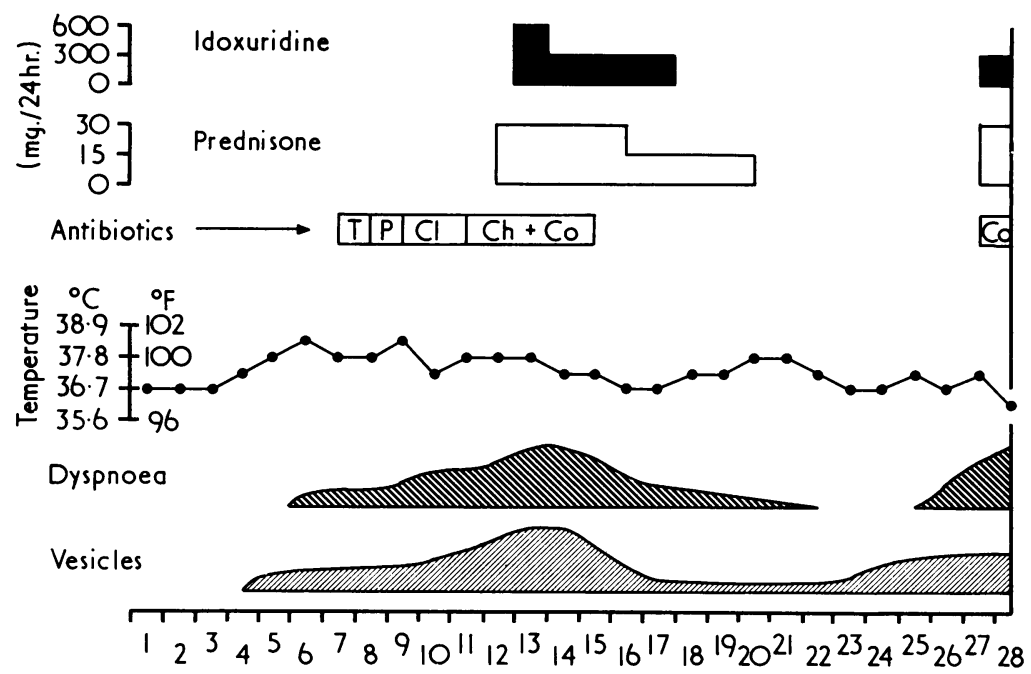

Days of life

FIG. 1.-Course and treatment of the infection. $\quad T=$ tetracycline, $P=$ penicillin, $C l=$ clomocycline, $C h=$ chloramphenicol, $\mathrm{Co}=$ colistin.

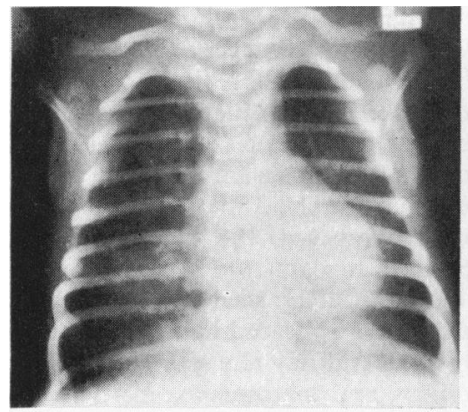

(a)

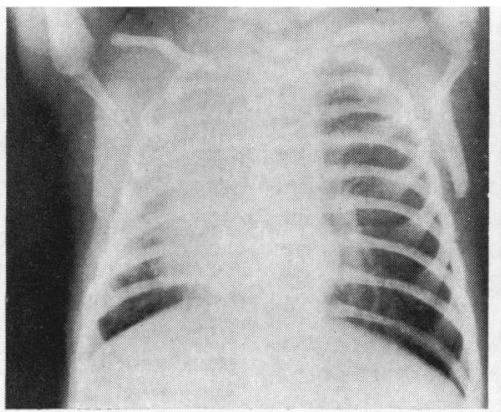

(b)

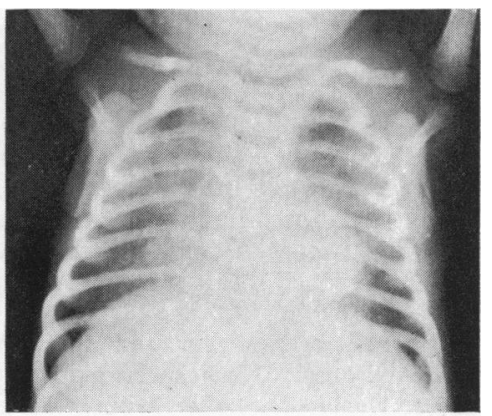

(c)

FIG. 2.-Chest $\mathrm{x}$-rays. (a) 7 days, (b) 13 days, (c) 22 days. Idoxuridine treatment was given from 13th to 17th day of life.

seen on the cervix, vagina, or vulva, and this time no virus was isolated. Papanicolaou smears of vagina and cervix showed no abnormality. The father developed penile herpes 24 days after the baby was born. The parents had not had intercourse since the latter part of pregnancy.
Necropsy. This was performed 3 hours after death. Macroscopical abnormalities were confined to the skin and the lungs. Several small macules (up to $0.3 \mathrm{~cm}$. diameter) were present in the skin of the right shoulder and left chest. There was a rash of yellowish-brown papules (up to $0.1 \mathrm{~cm}$. diameter) over the cheeks and

TABLE I

Cerebrospinal Fluid Findings

\begin{tabular}{|c|c|c|c|c|c|c|}
\hline \multirow{2}{*}{$\begin{array}{c}\text { Age } \\
\text { (days) }\end{array}$} & \multirow{2}{*}{$\mathrm{RBC} / \mathrm{cu} . \mathrm{mm}$. } & \multicolumn{2}{|c|}{ WBC/cu.mm. } & \multirow{2}{*}{$\begin{array}{c}\text { Protein } \\
\text { (g./100 ml.) }\end{array}$} & \multirow{2}{*}{$\begin{array}{c}\text { Sugar } \\
(\mathrm{mg} . / 100 \mathrm{ml} .)\end{array}$} & \multirow{2}{*}{$\begin{array}{l}\text { Bacteriological } \\
\text { Culture }\end{array}$} \\
\hline & & Neutophils & Lymphocytes & & & \\
\hline $\begin{array}{l}11 \\
17 \\
27\end{array}$ & $\begin{array}{l}360 \\
890\end{array}$ & $\begin{array}{l}2 \\
40 \\
\text { Hea }\end{array}$ & $\begin{array}{c}120 \\
36 \\
\text { ontaminated wi }\end{array}$ & $\begin{array}{r}60 \\
90 \\
\text { ood } \quad\end{array}$ & $\begin{array}{l}50 \\
43\end{array}$ & $\begin{array}{l}\text { Sterile } \\
\text { Sterile } \\
\text { Sterile }\end{array}$ \\
\hline
\end{tabular}


TABLE II

Details of Intravenous Idoxuridine

\begin{tabular}{c|c|c|c}
\hline Age (dy.) & Dose (mg.) & \multicolumn{1}{|c|}{ Diluent } & $\begin{array}{c}\text { Duration } \\
\text { (hr.) }\end{array}$ \\
\hline 13 & 600 & $120 \mathrm{ml} .5 \%$ dextrose & 6 \\
14 & 300 & $150 \mathrm{ml} .5 \%$ dextrose & 6 \\
15 & 300 & $500 \mathrm{ml} .5 \%$ dextrose & 24 \\
16 & 300 & $500 \mathrm{ml} .4 \%$ dextrose & 24 \\
17 & 300 & N/5 saline & \\
& & No0 ml. 4\% dextrose & 24 \\
& & & \\
\hline
\end{tabular}

Weight of baby (on 13th day of life) $3 \cdot 12 \mathrm{~kg}$. Total dose given $1800 \mathrm{mg}$. ( $580 \mathrm{mg} . / \mathrm{kg}$. body weight).

chin. Approximately $10 \mathrm{ml}$. clear, dark yellow fluid were present in each pleural cavity. The pink-red lungs felt firm; scattered throughout all lobes there were yellowish-grey foci (up to $0.3 \mathrm{~cm}$. diameter); at the surface these appeared as grey vesicles.

Histological examination revealed abnormalities in the skin, lungs, brain, and spinal cord.

Skin. Sections of the macules showed abnormal epithelial cells with large or double nuclei, and collections of inflammatory cells (lymphocytes, neutrophil polymorphs, histiocytes, and plasma cells).

Lungs. Sections showed foci of necrosis each affecting approximately $12-20$ alveoli, which contained eosinophilic debris and many Gram-positive cocci and Gram-negative bacilli. There was little inflammatory response to these foci. Throughout the lungs, alveolar septa were broadened and contained many inflammatory cells, including lymphocytes, histiocytes, plasma cells,

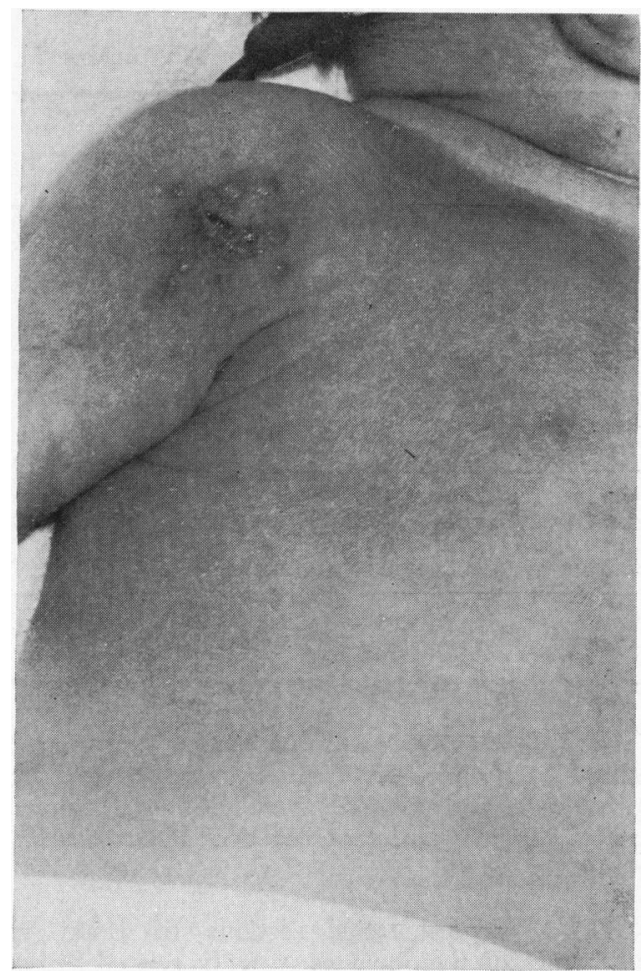

FIG. 3.-Age 13 days. Herpetic vesicles on right shoulder and one healing vesicle on the neck.
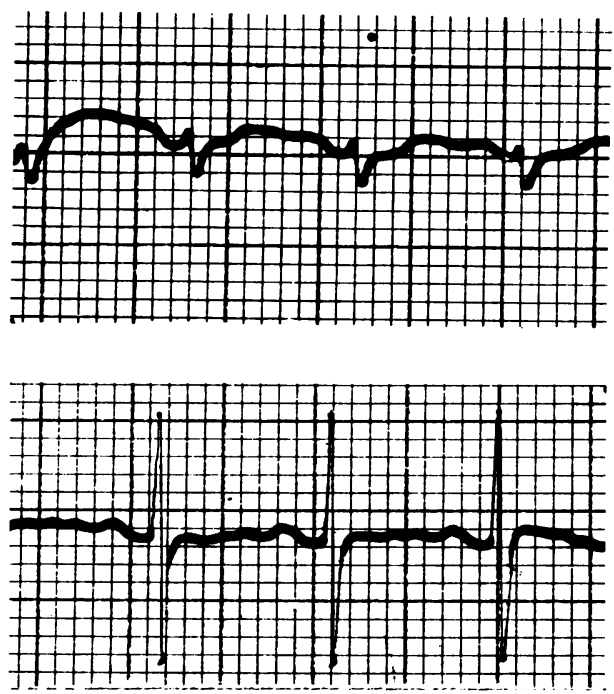

(b)

(a)

FIG. 4.-ECG leads (I and V3), (a) 13 days, (b) 22 days. 
TABLE III

Results of Tissue Culture for Herpes Simplex Virus

\begin{tabular}{|c|c|c|c|c|}
\hline \multicolumn{3}{|l|}{ Source } & $\begin{array}{l}\text { Days From } \\
\text { Patient's } \\
\text { Birth }\end{array}$ & Result \\
\hline $\begin{array}{l}\text { Patient } \\
\text { Vesicle fluid .. } \\
\text { Throat/nose swab } \\
\text { CSF . . } \quad . \\
\text { Throat swab .. } \\
\text { Throat swab .. } \\
\text { CSF . . } \quad \text {. } \\
\text { Post-mortem brain, } \\
\text { pleural, and peric } \\
\text { fluid }\end{array}$ & $\begin{array}{l}\ldots \\
\ldots \\
\ldots \\
\ldots \\
\ldots \\
\text { liver, } \\
\text { cardial } \\
\ldots\end{array}$ & $\begin{array}{c}\ldots \\
\ldots \\
\ldots \\
\ldots \\
\ldots \\
\ldots\end{array}$ & $\begin{array}{l}10 \\
10 \\
17 \\
20 \\
24 \\
27 \\
\\
\\
\end{array}$ & $\begin{array}{l}\text { Positive } \\
\text { Positive } \\
\text { Negative } \\
\text { Negative } \\
\text { Negative } \\
\text { Negative } \\
\\
\text { Negative }\end{array}$ \\
\hline $\begin{array}{l}\text { Mother } \\
\text { Vaginal swab. . } \\
\text { Vaginal swab.. } \\
\text { Cervical swab }\end{array}$ & $\begin{array}{l}\cdots \\
\cdots \\
\cdots\end{array}$ & $\begin{array}{l}\cdots \\
\cdots \\
\cdots\end{array}$ & $\begin{array}{l}14 \\
43 \\
43\end{array}$ & $\begin{array}{l}\text { Positive } \\
\text { Negative } \\
\text { Negative }\end{array}$ \\
\hline $\begin{array}{l}\text { Father } \\
\quad \text { Penile swab .. }\end{array}$ & .. & $\ldots$ & 28 & Positive \\
\hline
\end{tabular}

eosinophil leucocytes, and occasional multinucleate giant cells. In places these cells were present in alveoli ; bronchioles appeared to be spared. Some arteries or arterioles showed partial obliteration of the lumen by intimal cells.

CNS. 11 representative sections of brain were taken. Foci of lymphocytes, usually related to small blood vessels, were seen in the basal ganglia and right frontal cortex. Sections of the spinal cord showed haemosiderin, together with small numbers of chronic inflammatory cells in the dura, predominantly lymphocytes and histiocytes, but including a few eosinophil leucocytes.

No significant abnormalities were seen in sections of left ventricle, liver, kidneys, pancreas, spleen, cervical and mesenteric lymph nodes, bone-marrow, costochondral junction, tonsils, thymus, thyroid, suprarenal, ovary, bladder, ileum, and pectoral muscle.

Although no inclusion bodies were seen in any section, the histological appearances in the sections of skin, lung, and brain were regarded as compatible with viral

\section{TABLE IV}

Virus Serology Titres

\begin{tabular}{c|c|c|c}
\hline Source & $\begin{array}{c}\text { Day from } \\
\text { Patient's } \\
\text { Birth }\end{array}$ & $\begin{array}{c}\text { Complement- } \\
\text { fixation Titre }\end{array}$ & $\begin{array}{c}\text { Neutralization } \\
\text { Titre }\end{array}$ \\
\hline Patient & $\begin{array}{c}11 \\
28 \\
\text { (post mortem) }\end{array}$ & $\begin{array}{c}<1: 8 \\
1: 8\end{array}$ & $1: 66$ \\
\hline Mother & 14 & $<1: 8$ & $1: 33$ \\
\hline Father & 14 & $1: 16$ & $1: 33$ \\
\hline
\end{tabular}

infection. The arterial changes seen in the lungs could not be explained.

Investigations. Blood counts were performed before, during, and up to one week after the course of idoxuridine. Apart from the presence of juvenile neutrophil leucocytes, the picture remained normal and platelets were plentiful. Two blood cultures were sterile. Faeces grew no pathogens. Throat and nose swabs grew normal commensals on 4 occasions, 'coliform bacilli' twice, and Pseudomonas pyocyanea once. Plasma protein electrophoresis (before the administration of $\gamma$-globulin) was normal for age; total protein $6 \cdot 3 \mathrm{~g} . / 100$ $\mathrm{ml}$. Serum aspartate aminotransferase was 21 international units and serum alanine aminotransferase 39 international units at 8 and 11 days, respectively, after the start of idoxuridine treatment. The CSF findings are shown in Table I.

A virus of herpes simplex morphology was seen in vesicle fluid taken on the 11th day and examined by electron microscopy. A smear taken from vesicle fluid on the 13th day examined by light microscopy suggested a lesion of viral aetiology though no inclusion bodies were seen.

Virus isolation. Conventional methods of tissue culture were used for virus isolation. Some attempts were unsuccessful because of overgrowth by antibiotic resistant bacteria. These have been omitted from the results, shown in Table III.

Virus serology. Herpes simplex complement-fixation titres (CFT) against a standard antigen, and neutralizing titres against the virus grown from the baby, were estimated on sera from the baby and her parents. Neutralizing tests were done in human amnion tissue culture. Titres were similar in samples of serum from mother and baby; neither showed any significant rise (Table IV). From this it seems likely that the maternal infection had not been recent and that the baby's antibodies were passively acquired.

\section{Discussion}

This case demonstrates some features of systemic herpes simplex infection of the newborn which are discussed elsewhere (MacCallum and Partridge, 1968).

Isolation of the virus from the mother's vagina, the prolonged interval between delivery and rupture of the membranes, and isolation of the virus from the baby's respiratory tract, suggest that the route of infection was from the liquor into the baby's air passages either before birth or during delivery. Resuscitation by intubation and positive pressure may have contributed to this. It is of interest that virus was recovered from the mother's vagina in the absence of overt signs of herpetic infection, but cervical lesions may have been missed.

Systemic idoxuridine was used with reluctance 
because of its reported toxicity. However, the white cell and platelet counts remained unaffected, the two aminotransferase estimations were normal, and there were no observed side-effects. In this case no comment can be made about possible long-term side-effects which might be expected to occur when a drug that interferes with DNA metabolism is used.

The main evidence that idoxuridine improved the baby's condition was clinical. The baby was moribund before treatment, improvement was noted within 48 hours, and was sustained until 11 days after treatment began. The skin lesions regressed and virus was not subsequently isolated from the throat. The improvement in the chest $x$-ray provided further evidence. The ECG changes were thought to be in keeping with pericardial involvement and the return to normal accompanied clinical signs of improvement. No lesions were seen in the heart at necropsy and virus was not isolated from the pericardial fluid. This suggests that either there had been no virus infection of the heart, or treatment had completely eradicated it. There are few references to cardiac involvement in disseminated herpes simplex infection of the newborn. The case of Bernard et al. (1961) showed ECG changes with atrioventricular dissociation, and there were histological lesions in the myocardium and in the bundle of His. The virus was cultured from the heart in the absence of recognizable lesions in the case of Witzleben and Driscoll (1965).

This phase of initial recovery, however, was followed by the reappearance of skin vesicles 6 days after treatment ceased. The second infusion of idoxuridine was withheld until late in the terminal relapse because of fear of toxicity. It was infused in the last 12 hours of life only. No virus was obtained from post-mortem material (brain, liver, and pleural and pericardial fluid) collected 3 hours after death. As the herpes simplex virus is usually easy to isolate, as it was before treatment in this case, these negative virus cultures may well be significant.

The part played in this illness by secondary infection with antibiotic resistant bacteria is difficult to assess. These were grown from throat and nose swabs, overgrew tissue cultures for virus isolation, were isolated at necropsy, and were seen in postmortem lung sections in large numbers. These findings suggest that the bacterial infection was contributory and that antibiotics should perhaps have been used for a longer period.

If idoxuridine were used again for this condition, which has such a poor prognosis, a different regimen might be more effective, either using larger doses, or prolonging therapy with doses spaced at intervals.

\section{Summary}

A newborn infant developed systemic herpes simplex infection. Skin vesicles appeared on the 4th day. The diagnosis was confirmed on the 13th day and intravenous idoxuridine started. A total of $580 \mathrm{mg}$. $/ \mathrm{kg}$. was given over 5 days, with clinical evidence of improvement. A relapse occurred at 23 days and the baby died aged 28 days. The postmortem findings are described. Further trial of idoxuridine in neonatal systemic herpes simplex is suggested.

All the virological investigations were performed by Dr. J. Nagington, and it is a pleasure to express gratitude for his help.

\section{REFERENCES}

Bernard, R., Payan, H., Tamalet, J., and Audibert, G. (1961). Herpès du nouveau-né avec dissociation auriculo-ventriculaire. Étude clinique, anatomique et virologique. Sem. Hôp. Paris, 37, 2653.

Calabresi, P. (1965). Clinical studies with systemic administration of antimetabolites of pyrimidine nucleosides in viral infections. Ann. N. Y. Acad. Sci., 130, 192.

MacCallum, F. O., and Partridge, J. W. (1968). Fetal-maternal relationships in herpes simplex. Arch. Dis. Childh., 43, 265.

Witzleben, C. L., and Driscoll, S. G. (1965). Possible transplacental transmission of herpes simplex infection. Pediatrics, 36, 192. 